\title{
Design For Europe: Employing Scenarios to Benchmark the Effectiveness of European Design Policy
}

Martyn Evans, Manchester School of Art, Manchester Metropolitan University, Manchester, UK

John Chisholm, Imagination Lancaster, Lancaster University, Lancaster, UK

\section{Introduction}

The paper draws on a two year EC funded research project 'DeEP: Design in European Policy' undertaken by the authors in collaboration with Politecnico di Milano (IT, Lead partner), University of Lancaster (UK), Malardaalens Hogskola (SE), Confartigianato Lombardia (IT), Munktell Science Park Eskilstuna Jernmanufaktu (SE), Pro Design (PL) and The Work Foundation (UK). The DeEP project aimed to better understand the impact of design in innovation policies through the development of frameworks and indicators with which to evaluate policy actions at both the macro (regional, national, European) and micro (specific initiative) level.

This paper i) discusses the design innovation policy agenda across Europe, ii) considers the challenge of evaluating macro-level design policy, and iii) presents a scenario-based approach to benchmarking the effectiveness of European design policy. The paper concludes with the challenges and limitations of evaluating macrolevel design innovation policies.

\section{Research Context}

Policy research in design may be differentiated through two emergent foci - design for policy and policies for design. This paper contributes to the understanding of the latter (policies for design). Design policy is government intervention aimed at stimulating the supply and demand for design to tackle failures in the way that actors and components interact in the national or regional design system. Design is a tool in the toolbox of innovation; the link between design and innovation is not new but it has not always been recognised at policy level.

In 2010, design became one of ten priorities for innovation in the over-arching European Commission policy 'Innovation Union', noting that 'our strengths in design 
and creativity must be better exploited' (European Commission, 2010:3). In the past few years, there has been a marked increase in the number of EU Member States and regions with design included within innovation policies. In 2012, Estonia launched their 'National Action Plan for Design' and in 2013, Denmark and Finland both launched strategies for design.

If design is to leverage a greater innovation capacity within companies, what evidence does government require to justify great public investment in design support? There is a disconnect between market-driven innovation in companies and government policy for innovation, and a general lack of design's evidence on GDP as a key priority action area, with the EDIl calling for the continued development of more effective and reliable methods for measuring the impact of investment in design on growth and social well-being, at the micro and macro levels, and for the inclusion of these within EU innovation statistics (EDII, 2013).

Moultrie and Livesey (2009:6) identify difficulties in providing comprehensive international comparisons for design capability due to a lack of reliable and comparable data - proposing the establishment of an on-going set of clearly defined measures 'to enable more effective measurement and comparison in the future'. Policy intervention in favour of design can be justified in terms of systems failure, where the role of government is to devise actions, programmes and policies aimed at stimulating the supply and demand for design to tackle failures in the way that actors and components of the system interact. In the same way that policies for innovation are based on an analysis of the national or regional innovation system, policies for design should be based on an understanding of the national or regional design system.

\section{The European Agenda for Design}

In recent years there has been an increasing recognition by policy makers of the potential for design, and a key driver of innovation, to add value to the competitiveness of Europe. The European Commission demonstrated their commitment to design, stating 
"There is political agreement in Europe that to ensure competitiveness, prosperity and wellbeing, all forms of innovation need to be supported. The importance of design as a key discipline and activity to bring ideas to the market, has been recognised in ... the Innovation Union, a flagship initiative of the Europe 2020 Growth Strategy" (European Commission, 2014).

In 2011 the European Commission established the European Design Leadership Board (EDLB) which was charged with making proposals enhance the role of design in innovation policy. Specifically the remit of the EDLB was "to provide recommendations on how to enhance the role of design in innovation policy in Europe at the national, regional or local level and to develop a joint vision, priorities and actions, and thenceforth to integrate design as a part of innovation policies in Europe."

In September 2012 the EDLB presented its recommendations to Vice-President Tajani at the European Design Innovation Summit in Helsinki. Design for Growth \& Prosperity (EDLB, 2012) included twenty-one policy recommendations, in six strategic areas for design action. This landmark report contributed to increased agenda for design in Europe and helped to raise the political recognition of the potential contribution to design in innovation policy. In this report the EDLB identified six strategic design actions (EDLB, 2012):

- Differentiating European design on the global stage

- Positioning design within the European innovation system

- Design for innovative and competitive enterprises

- Design for an innovative public sector

- Positioning design research for the 21st century

- Design competencies for the 21st century

The EDLB provide unequivocal evidence of the increasing recognition of design in the political agenda in Europe, stating "Never before has so clear an opportunity existed as now, for the European Commission, Member States and regions to take 
bold action to enable a new level of awareness about the importance of design as a driver of user-centred innovation across Europe" (EDLB, 2012:5).

The political agenda for design policy in Europe has continued to develop with increased awareness of, and attention being paid to, design as a driver for innovation. Through the Action Plan for Design-Driven Innovation (European Commission, 2013) the Commission seeks to actively promote design's relevance and value as an enabler of innovation amongst Europe's enterprises, public sector organisations and policy-makers. This internal Commission 'staff working document' asserts that "A more systematic use of design as a tool for user-centred and marketdriven innovation in all sectors of the economy, complementary to R\&D, would improve European competitiveness" (European Commission, 2013:04).

Against this backdrop, an appreciation of the picture of European design is a valuable precursor to understanding how design policy might affect European business and society through its impact on the elements that comprise the design policy landscape. The EDLB report identifies a number of key characteristics of design in Europe. These include:

- Over 410,000 professionally-trained designers practicing in Europe operating either within the design-services consulting sector as independent, external consultants, or 'in-house' in medium and large companies with a dedicated design function.

- Multi-disciplinary, national professional associations representing the interests of qualified, professional designers.

- Trade associations representing design businesses are also present in a number of member states.

- Publicly-funded national and/or regional design promotion organisations, representing the visible face of design promotion at national and regional level.

- An extensive network of design schools across Europe. 
As one of the EDII funded projects, the SEE Project ${ }^{1}$ has comprehensively reviewed design innovation policy across Europe. The 'Design Policy Monitor 2012' concluding that whilst design can be explicitly referred to in EU member states' innovation policy, the gap between government statements on design and the implementation of design policy initiatives is marked. Reasons cited for this include a lack of evidence 'in the form of consistent and comparable statistics on the micro and macro performance of design across Europe' (Whicher et al. 2013:3).

Understanding at a national level the relationship between the various activities and organisation that drive design within nations is important to policy makers. While it is clear that there is political will underpinning the elevation of design as a pillar for European competitiveness and prosperity, the lack of consentient and effective data on the 'state-of-the-art' of design across Europe is challenging.

\section{A Design Innovation Ecosystem}

At a national level design the contribution that design makes to competitiveness and prosperity can involve many organisations, agendas and interactions. This, we believe, can be conceptualised as a design innovation ecosystem and as such potentially provide a means to formalise this complex interrelated system. We define a national design innovation ecosystem as "the actors, context(s) and interactions required to support design as an enabler of people centred-innovation". This is a complex, interrelated and multi-layered environment in which design innovation policy operates. The boundaries of a national design innovation ecosystem are to an extent porous and interaction with other ecosystems, both geographically and sectorially defined is acknowledged. The idea of the national design innovation ecosystem enabled us to conceptualise the extent to which a given member state engages with design innovation policy and provides a means of capturing the actors, context(s) and interactions required to move forward design as a driver for innovation.

While the notion of a national design innovation ecosystem helps to conceptualise the manner in which design operates within nations, the lack of data relating explicitly

\footnotetext{
1 Now funded as the SEE Platform, one of the six European Design Innovation Initiative (EDII) projects.
} 
to design innovation policy and the lack of evaluation instruments required to demonstrate the efficacy of existing policy provides a key challenge to understanding how well a nations ecosystem is operating and its fitness for purpose. Evaluation of macro level design policy requires datasets across a range of indicators that are representative of the focus of the evaluation, in the context of our research this is design innovation.

A limiting factor in this process is the relative paucity of macro design indicators spanning all EU member states, particularly in comparison to the availability of innovation indicators. Similarly, data for design indicators is not collected as frequently, nor as consistently across Europe, as that collected for innovation or more general socio-economic indicators.

Due to the desire to identify macro indicators that i) utilise existing data sources, and ii) were available for as many member states as possible, the process of selection of macro design indicators was challenging. For a detailed discussion of the development and selection of macro design indicators see DeEP Policy Issues No.2 (Evans \& Chisholm, 2014).

We have resisted the temptation to adopt innovation indicators as a proxy for design indicators, despite the fact that the compilation of full datasets for all EU member states will not be possible from the outset. Existing macro design indicators have been selected through an interpretation of the most useful and usable indicators in the context of our research, organised into three macro design categories which reflect the enabling role of design in innovation.

- Design Investment - representing a governments' investment in design in both financial $(€)$ and policy terms

- Design Supply - reflecting the education, training and supply of design practitioners - including wider education and training provision

- Design Sector - relating to the national design industry as providers of design skills and expertise. NB: this includes the 'creative industries', but also 'in-house' design 
These categories are based on an analysis of existing macro design indicators derived from published reports and surveys and have been synthesised from an optimal list of available macro design indicators.

Macro design indicators developed through our research are listed below:

\begin{tabular}{|l|l|l|}
\hline $\begin{array}{l}\text { MARCO DESIGN } \\
\text { CATEGORY }\end{array}$ & $\begin{array}{l}\text { MARCO DESIGN } \\
\text { INDICATORS }\end{array}$ & DATA SOURCE \\
\hline $\begin{array}{l}\text { Design } \\
\text { Investment }\end{array}$ & $\begin{array}{l}\text { Public Investment in Design } \\
\text { Support (as \% of GDP) }\end{array}$ & $\begin{array}{l}\text { International Design } \\
\text { Scoreboard }\end{array}$ \\
\cline { 2 - 3 } & $\begin{array}{l}\text { Public Investment in Design } \\
\text { Promotion (as \% of GDP) }\end{array}$ & $\begin{array}{l}\text { International Design } \\
\text { Scoreboard }\end{array}$ \\
\cline { 2 - 3 } & $\begin{array}{l}\text { Government Spend on Design } \\
\text { Services (as \% of GDP) }\end{array}$ & $\begin{array}{l}\text { Official Journal of the } \\
\text { European Union (OJEU) }\end{array}$ \\
\hline \multirow{5}{*}{ Design Supply } & $\begin{array}{l}\text { Design Courses at Graduate } \\
\text { Level (as \% of all courses) }\end{array}$ & $\begin{array}{l}\text { OECD - Education at } \\
\text { a Glance }\end{array}$ \\
\cline { 2 - 3 } & $\begin{array}{l}\text { Design Courses at Postgraduate } \\
\text { Level (as \% of all courses) }\end{array}$ & $\begin{array}{l}\text { OECD - Education at } \\
\text { a Glance }\end{array}$ \\
\cline { 2 - 3 } & $\begin{array}{l}\text { Design Graduates (per million } \\
\text { population) }\end{array}$ & $\begin{array}{l}\text { International Design } \\
\text { Scoreboard }\end{array}$ \\
\hline \multirow{5}{*}{ Design Sector } & $\begin{array}{l}\text { No. of Design Businesses (per } \\
\text { million population) }\end{array}$ & $\begin{array}{l}\text { International Design } \\
\text { Scoreboard }\end{array}$ \\
\cline { 2 - 3 } & $\begin{array}{l}\text { Turnover of Design Services } \\
\text { Sector (as a \% of GDP) }\end{array}$ & $\begin{array}{l}\text { International Design } \\
\text { Scoreboard }\end{array}$ \\
\cline { 2 - 3 } & $\begin{array}{l}\text { Creative Services (Exports) (as } \\
\text { a \% of total services trade) }\end{array}$ & $\begin{array}{l}\text { UN Conference of } \\
\text { Trade \& Development }\end{array}$ \\
\hline
\end{tabular}

Table 1. Macro design categories, associated indicators and data source.

This above list of proposed macro design indicators provides a manageable and representative palette of indicators to guide policymakers in the majority of design innovation policy initiatives. However these indicators clearly focus on design and do not include the broader macro-economic context. We did not include such indicators in its approach as we believe that there is a wealth of such data available and it would be foolish to believe that this should be replicated within this project. Our position is to advocate the use of available macro-economic data to provide a broad landscape in which design innovation policy is played out.

Macro-economic indicators are likely to be concentrated in the early and later stages of the policy cycle. They are primarily likely to be part of an evaluation framework through: 
a) Baseline data which provides part of the agenda setting process - ex-ante (e.g. 'we can identify that there are fewer design jobs in $x$ region of $x$ country compared to the European average - this may call for policy intervention')

b) Measures of impact some distance down the 'chain' of impacts - ex-post (e.g. 'we can now see, 3 years after the policy implementation, that there are the same number of design jobs as a $\%$ of employment in region $\mathrm{x}$ of country $\mathrm{x}$ compared to the European average')

c) Providing the context within which to both determine and evaluate policy and policy impacts. For example GDP, total population, population of working age etc.

Macro-economic indicators are likely to be placed a the 'beginning' and 'end' of the evaluation structure in the policy cycle because, although they are powerful measures (indeed, indicators of the ultimate primary goals of many policy initiatives), they are often highly aggregated, and provide little indication of the causal 'path' of impact for a specific policy - which are likely to be filled with micro indicators within the evaluation framework.

The development of a set of macro-indicators for evaluating a specific policy initiative will include design macro-indicators which could then be later related to a complementary set of non-design macro-economic indicators as appropriate.

\section{The Challenge of Evaluation - A Scenario Approach?}

Evaluating macro-level design policy relies on the availability of data. This is a significant challenge for design policy as simply data is not available across all EU member states. Paasi (2005) notes that 'very often the selection of indicators is not limited by technical or theoretical understanding, but by the restricted availability of timely, comparable and harmonized data'. The selection of the macro design policy indicators does provide limitations in terms of the availability of data across the EU.

Where data is available, evaluation provide national with an understanding of their relative performance against other nations through a process of benchmarking. Benchmarking provides a means of comparing the relative performance of EU member states through aggregation of data for macro design innovation policy 
indicators. The concept of benchmarking - "an ongoing, systematic process for measuring and comparing ... with an external standard" (Alstete, 1995) - provides EU member states with a mechanism to assess how well they are performing when compared to others. The aggregation of data for the nine macro design innovation policy indicators also enables the creation of an EU benchmark. Such an EU wide benchmark enables comparison of the relative performance of member states against the EU 'standard'.

Paasi (2005) used the term 'collective benchmarking' to denote comparisons across a number of countries. Collective benchmarking provides a route to agreed indicators for the measurement and comparison of performances, and identification of successful, best practice policies performed by the best performer. As a result it enables learning through interactions among governments and nations.

While Niosi (2002) asserts that benchmarks are 'indicators of best practice', in the context of design policy in Europe, they provide opportunity to compare relative performance of member states. In turn this provides the opportunity to identify the 'best-in-class' as exemplars of design innovation policy. By understand their relative position, member states can look to learn from well performing nations.

To make the data more accessible to users and to support easier comparison, data should be 'normalised' through mapping the original data range onto a common scale. This approach is one that is already used in relation to benchmarking in the EU (OECD, 2013) and as such is adopted for this purpose in our research.

While the use of national benchmarking data is a very useful quantitative tool for assessing the relative performance of a member state, there is also a need to translate data into a form that communicates the underlying implications of the data. We employed a narrative approach, in the form of scenarios, to describe the contextual characteristics of performance 'above' and 'below' the EU benchmark across the three macro design innovation policy indicator categories: Design Investment, Design Supply, and Design Sector. The use of scenarios is proposed as it presents a description of the likely national context for a given member state when 

categories.

\section{Scenario: A narrative describing possible situations signified by the indicators - with an emphasis on causes and effects observed towards the edges of the spectrum.}

\begin{tabular}{|c|c|c|c|c|c|}
\hline & INV & SUP & SEC & SUMMARY & SCENARIO \\
\hline & 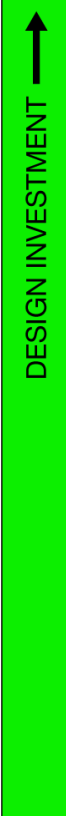 & 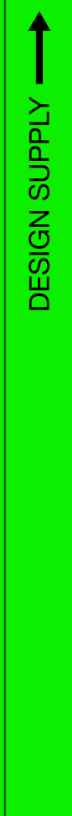 & 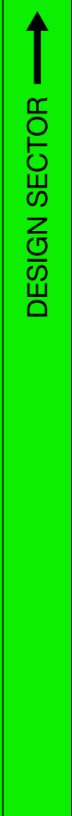 & $\begin{array}{l}\text { Above average } \\
\text { levels of public } \\
\text { investment in } \\
\text { design, design } \\
\text { sector activity } \\
\text { and supply of } \\
\text { design } \\
\text { graduates. }\end{array}$ & $\begin{array}{l}\text { - A strong awareness of national } \\
\text { design running throughout government, } \\
\text { business and the sector. National } \\
\text { government is able to demonstrate a } \\
\text { strong commitment to supporting and } \\
\text { maintaining national design capability as } \\
\text { a national asset. } \\
\text { - A coherent and balanced national } \\
\text { design system (whether formally } \\
\text { established or not) has resulted in a } \\
\text { balanced national design policy } \\
\text { eco-system able to meet demand for } \\
\text { design services driven by a strong } \\
\text { awareness of the value of design in } \\
\text { business. } \\
\text { - A skilled, confident and enterprising } \\
\text { design service sector providing high } \\
\text { quality employment and offering vibrant } \\
\text { and dynamic career paths for designers. } \\
\text { - Finely tuned supply of design } \\
\text { graduates with an appropriate mix of } \\
\text { specialisms and competencies } \\
\text { supplying both the design services } \\
\text { sector and wider business. }\end{array}$ \\
\hline 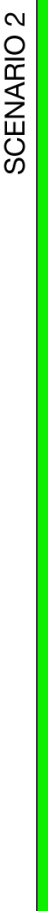 & 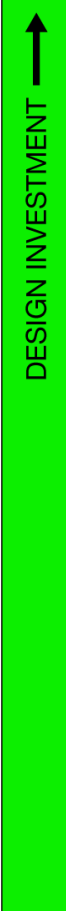 & 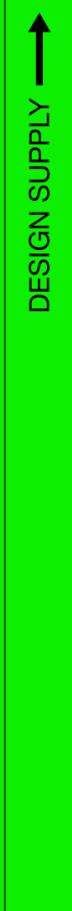 & 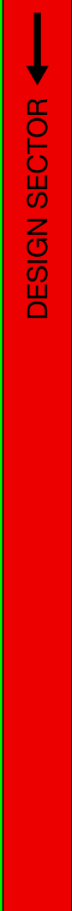 & $\begin{array}{l}\text { Below average } \\
\text { levels of design } \\
\text { sector activity; } \\
\text { above average } \\
\text { levels of public } \\
\text { investment in } \\
\text { design and } \\
\text { above average } \\
\text { supply of } \\
\text { design } \\
\text { graduates. }\end{array}$ & $\begin{array}{l}\text { - Despite higher than average levels of } \\
\text { public investment in design, the design } \\
\text { services sector has not responded with } \\
\text { a corresponding uplift in levels of activity } \\
\text { or performance. This may indicate poor } \\
\text { targeting of the promotion and support } \\
\text { of design or a misunderstanding of the } \\
\text { intended audience and its needs. } \\
\text { - It may indicate that the needs of } \\
\text { business are not met by the current } \\
\text { orientation and skillsets of the design } \\
\text { services sector - needs that are being } \\
\text { met elsewhere. } \\
\text { - Despite an understanding of, and } \\
\text { commitment to, design - in practice, } \\
\text { making effective investments in design } \\
\text { has not been fully understood or } \\
\text { implemented. } \\
\text { - Higher than average levels of design } \\
\text { supply compared to lower levels of } \\
\text { design sector activity might suggest that } \\
\text { too many design courses are producing } \\
\text { too many graduates - or graduates with } \\
\text { mismatched skillsets - and that the } \\
\text { supply of design graduates exceeds } \\
\text { that which the design services sector } \\
\text { can absorb. }\end{array}$ \\
\hline
\end{tabular}


Table 2. Macro design innovation policy scenarios to support benchmarking of national design contexts.

\begin{tabular}{|c|c|c|c|c|c|}
\hline & INV & SUP & SEC & SUMMARY & SCENARIO \\
\hline & 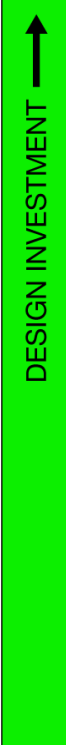 & $\begin{array}{l}\downarrow \\
\text { ta } \\
0 \\
0 \\
0 \\
0 \\
z \\
\frac{0}{\omega} \\
山 \\
0\end{array}$ & 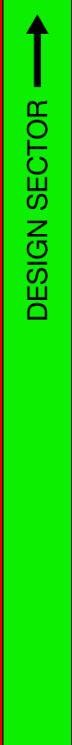 & $\begin{array}{l}\text { Above average } \\
\text { levels of public } \\
\text { investment in } \\
\text { design and } \\
\text { levels of design } \\
\text { sector activity; } \\
\text { below average } \\
\text { supply of } \\
\text { design } \\
\text { graduates. }\end{array}$ & $\begin{array}{l}\text { - A strong awareness of the value of } \\
\text { design in business resulting from higher } \\
\text { than average levels of public investment } \\
\text { in design has not been matched by the } \\
\text { capacity in design supply - the numbers } \\
\text { of design courses and design graduates } \\
\text { may be insufficient to meet demand. } \\
\text { - Supply of design graduates does not } \\
\text { meet demand. There are insufficient } \\
\text { graduates compared to the ability of } \\
\text { business and the design services sector } \\
\text { to absorb them. Competition for } \\
\text { graduates is high within the design } \\
\text { services sector and wider business. } \\
\text { - Investment in design has generated } \\
\text { more demand for design graduates than } \\
\text { the design services sector can meet or, } \\
\text { by implication, business in general can } \\
\text { source. } \\
\text { - Overseas outsourcing of design } \\
\text { services and/or design graduates may } \\
\text { be required to meet national demand. }\end{array}$ \\
\hline 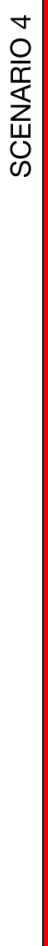 & 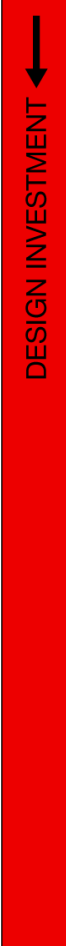 & 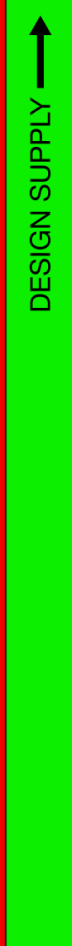 & 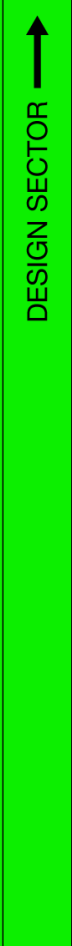 & $\begin{array}{l}\text { Below average } \\
\text { levels of public } \\
\text { investment in } \\
\text { design; above } \\
\text { average levels } \\
\text { of design } \\
\text { sector activity } \\
\text { and supply of } \\
\text { design } \\
\text { graduates. }\end{array}$ & $\begin{array}{l}\text { - Below average levels of investment in } \\
\text { design support and promotion indicate } \\
\text { a market-driven philosophy where levels } \\
\text { of investment in design is determined } \\
\text { and sourced from the wider market for } \\
\text { design and the supply of design. } \\
\text { - Effective and performing design } \\
\text { sector despite limited government } \\
\text { support for design. Vibrant and dynamic } \\
\text { career paths for designers continue } \\
\text { within a healthy design sector. } \\
\text { - A functioning market-driven model } \\
\text { with limited policy intervention. Demand } \\
\text { for design services is balanced with } \\
\text { ability of supply of design graduates to } \\
\text { meet demand, but equilibrium may be } \\
\text { may jeopardised in the future should a } \\
\text { sustained period of below average } \\
\text { public investment in design continue. } \\
\text { - The nature of the role of government } \\
\text { in generating and maintaining support } \\
\text { and awareness of design may be } \\
\text { misunderstood. A market forces, } \\
\text { 'laissez-faire' philosophy may work well } \\
\text { in the short-term, but a central } \\
\text { understanding of design as enabler of } \\
\text { innovation will be needed for long-term } \\
\text { sustainability. }\end{array}$ \\
\hline
\end{tabular}


Table 2. Continued.

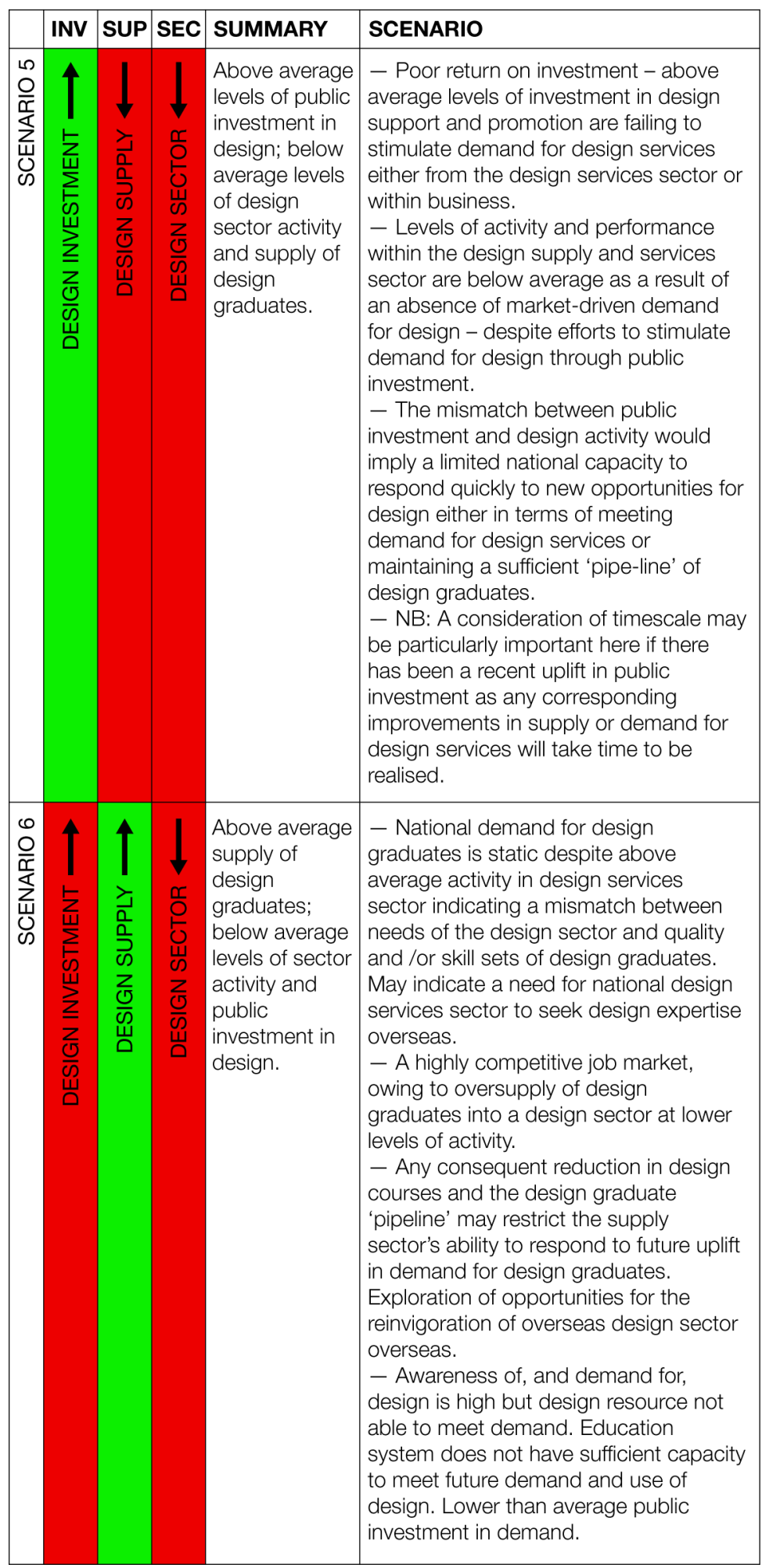


Table 2. Continued.

\begin{tabular}{|c|c|c|c|c|}
\hline INV & SUP & SEC & SUMMARY & SCENARIO \\
\hline 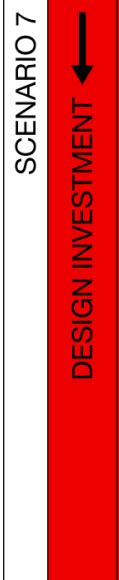 & 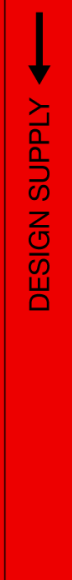 & 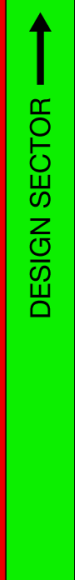 & $\begin{array}{l}\text { Above average } \\
\text { levels of design } \\
\text { sector activity; } \\
\text { below average } \\
\text { public } \\
\text { investment in } \\
\text { design and } \\
\text { supply of } \\
\text { design } \\
\text { graduates. }\end{array}$ & $\begin{array}{l}\text { - Lower than average public } \\
\text { investment in design indicates that the } \\
\text { value of design is not seen as a key } \\
\text { asset of national culture; the capacity to } \\
\text { supply design skills low in comparison } \\
\text { with demand from the design sector; } \\
\text { overall awareness of design and the } \\
\text { value of design in business may be low. } \\
\text { - A vibrant design sector despite } \\
\text { limited government support for design } \\
\text { may indicate a market driven model with } \\
\text { limited policy intervention. } \\
\text { - Supply of graduates does not meet } \\
\text { domestic demand possibly resulting in } \\
\text { outsourcing of design overseas and/or } \\
\text { employment of overseas design } \\
\text { professionals/graduates. }\end{array}$ \\
\hline 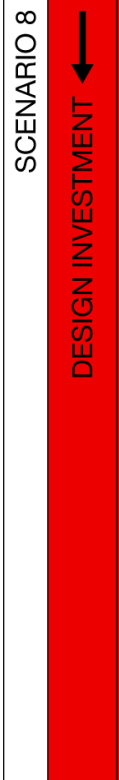 & 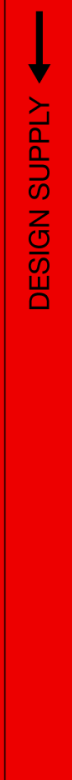 & 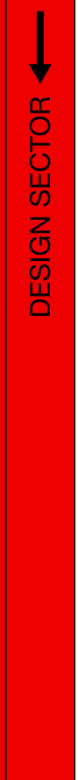 & $\begin{array}{l}\text { Below average } \\
\text { levels of public } \\
\text { investment in } \\
\text { design, design } \\
\text { sector activity } \\
\text { and supply of } \\
\text { design } \\
\text { graduates. }\end{array}$ & $\begin{array}{l}\text { - Little awareness or understanding of } \\
\text { design within government and where } \\
\text { the value of design is not seen as a key } \\
\text { asset of national culture. Lack of design } \\
\text { investment has resulted in a limited } \\
\text { national capacity to respond quickly to } \\
\text { new opportunities for design. } \\
\text { - Levels of activity and performance } \\
\text { within the design supply and services } \\
\text { sector are below average as a result of a } \\
\text { lack of stimulus from government and/or } \\
\text { an absence of market-driven demand } \\
\text { for design. } \\
\text { - A limited, possibly incoherent design } \\
\text { services sector serving only a proportion } \\
\text { of potential businesses requiring design } \\
\text { services. Limited career paths for } \\
\text { designers. } \\
\text { - Limited supply of design graduates } \\
\text { with a limited range of specialisms and } \\
\text { competencies supplying both the } \\
\text { design services sector and wider } \\
\text { business. }\end{array}$ \\
\hline
\end{tabular}

Table 2. Continued.

These eight scenarios provide a line of best fit between the benchmark data and description of the national context in terms of macro design innovation policy indicators. While this provides an interpretation of the likely national context it is limited as it does not facilitate a detailed description of a particular member state. Rather this approach describes in broad terms the characteristics of performance 
against the EU benchmark. Further empirical effort is required to ensure these scenarios align effectively with the specific characteristics of all member states.

\section{Challenges and limitations}

Macro level evaluation of design policies and initiatives is extremely challenging primarily due to the lack of availability of quantitative data across all member states. Selection of macro indicators was underpinned by the following principles:

- That where possible pan-European data that should be employed, i.e. data already collected across the EU such as OECD 'Education at a Glance'

- That indicators should be selected where existing data is available across some, if not all, member states

- That data should be comparable across member states, i.e. when collected by individual member states the data should be methodologically robust

- That data should be collected at comparable timeframes

Paasi (2005) notes that "very often the selection of indicators is not limited by technical or theoretical understanding, but by the restricted availability of timely, comparable and harmonized data'. The selection of the macro indicators does provide limitations in terms of the availability of data across the EU. As a consequence, sample data for four countries was used to illustrate the approach proposed for the benchmarking of macro indicators. We acknowledge that the actual data presented is limited in nature and any conclusions drawn should be treated accordingly.

Our research identified that there are key limitations related to the selection of the macro indicators including: the combination of data coming from various sources may be unreliable; data was often collected for different purposes (and thus the motivation of data collection cannot be guaranteed as being impartial); data was collected using different methodological approaches (and this is not always communicated by the owner of the data, that the point when data was collected differs and covers varying timeframes; and data was only available all nine indicators from a small number of member states. 
While these limitations may be considered to undermine the research approach adopted, it is important to recognise the challenge faced at a macro level in the identification of reliable and available indicators. There are no reliable and comprehensive data sets currently available for design across Europe. One of the other EDII projects - €Design - has also encountered limitations in data availability across Europe. We have developed a methodological approach for macro evaluation of design innovation policies that is robust but is dependent, to an extent, on more effective and comprehensive data collection. What is clear is that to make a compelling and credible case for design in Europe there is a distinct need for more European wide data collection initiatives. Plans to include specific questions on design in the Community Innovation Survey (CIS) in the next few years will go some way to address this shortcoming but further activities are required if design is to be elevated to the same level as innovation across the EU.

\section{References}

Alstete, J (1995) Benchmarking in Higher Education: Adapting Best Practices To Improve Quality. ASHE-ERIC Higher Education Report No.5. ERIC Clearinghouse on Higher Education. Washington, DC.

Evans, M \& Chisholm, R (2014) DeEP Policy Issues No.2. DeEP: Design in European Policy. Lancaster University. Lancaster, UK. Available from: https://www.academia.edu/8628827/DeEP Research_Design_Policy Issues 2 Accessed: 23 January 2015

Thomson, M \& Koskinen, T (eds) (2012) Design for Growth \& Prosperity: Report and Recommendations of the European Design Leadership Board. European Design Innovation Initiative. DG Enterprise and Industry. Brussels. Available from: http://ec.europa.eu/enterprise/policies/innovation/files/design/design-for-growthand prosperity-report en.pdf. Accessed 12 January 2015 European Commission (2010) Europe 2020: A strategy for smart, sustainable and inclusive growth. COM(2010) 2020 final of 3.3.2010. Brussels.

European Commission (2013) Implementing an Action Plan for Design-Driven Innovation. SWD(2013) 380 final of 23.9.2013. Brussels.

European Commission (2014) Design for innovation. Retrieved from http://ec.europa.eu/enterprise/policies/innovation/policy/designcreativity/index_en.htm Accessed 17 April 2014 
Moultrie, J \& Livesey, F (2009) International Design Scoreboard: Initial indicators of international design capabilities. Institute for Manufacturing, University of Cambridge, UK.

Niosi, J (2002) National Systems of Innovation are X-Efficient, Research Policy, Elsevier Science, 31 (2): pp. 291-302, 2002. Philadelphia PA, USA.

OECD (2013) Innovation Union Scoreboard 2013. Organisation for Economic Cooperation and Development. Available at

http://ec.europa.eu/enterprise/policies/innovation/facts-figures-analysis/innovationscoreboard/index en.htm Accessed 15 December 2014

Paasi, M (2005) Collective benchmarking of policies: an instrument for policy learning in adaptive research and innovation policy. Science and Public Policy 32, 17-27. Whicher, A, Cawood, A \& Walters, A (2013) Design Policy Monitor 2012: Reviewing Innovation and Design Policies Across Europe. SEE Platform. Design Wales/PDR, Cardiff Metropolitan University. Cardiff, UK. 